\title{
Thiocyanate stabilizes AMPA binding to the quisqualate receptor
}

\author{
Elsebet Ø. Nielsen ${ }^{1}$, Jang-Ho J. Cha, Tage Honoré ${ }^{1}$, John B. Penney and Anne B. Young * \\ Department of Neurology and The Neuroscience Program, University of Michigan, Neuroscience Laboratory Building, 1103 E. Huron, \\ Ann Arbor, MI 48104-1687, U.S.A., and 'A/S Ferrosan, Research Division, Sydmarken 5, DK-2860 Soeborg, Denmark
}

Received 16 August 1988, accepted 23 August 1988

Calcium and chloride ions stimulated $\left[{ }^{3} \mathrm{H}\right]$ glutamate binding to quisqualate-sensitive $\left[{ }^{3} \mathrm{H}\right]$ glutamate binding sites 4-fold, as measured by quantitative autoradiography, whereas $100 \mathrm{mM}$ potassium thiocyanate had no additional effect. In contrast, calcium and chloride had little effect on the binding of $\left[{ }^{3} \mathrm{H}\right](\mathrm{RS})-\alpha$-amino-3-hydroxy-5-methylisoxazole-4proprionic acid $\left(\left[{ }^{3} \mathrm{H}\right] \mathrm{AMPA}\right)$, but $100 \mathrm{mM}$ thiocyanate stimulated binding 4-fold. AMPA displaced little $\left[{ }^{3} \mathrm{H}\right] \mathrm{gluta}$ mate binding from quisqualate-sensitive binding sites in the molecular layer of the cerebellum in the absence of thiocyanate. However, in the presence of thiocyanate AMPA became a more effective displacer, but still displaced only $44 \%$ of the quisqualate-sensitive $\left[{ }^{3} \mathrm{H}\right]$ glutamate binding. The distribution of $\left[{ }^{3} \mathrm{H}\right]$ glutamate binding to quisqualate-sensitive sites was similar to but not identical with that of $\left[{ }^{3} \mathrm{H}\right] \mathrm{AMPA}$ binding. However, the distribution of AMPA-displaceable $\left[{ }^{3} \mathrm{H}\right]$ glutamate binding correlated highly $(\mathrm{r}=0.97, \mathrm{P}<0.0005)$ with that of $\left[{ }^{3} \mathrm{H}\right] \mathrm{AMPA}$ binding. The results suggest that AMPA binds to a subclass of quisqualate-sensitive $\left[{ }^{3} \mathrm{H}\right]$ glutamate binding sites that are highly influenced by ionic environment and that quisqualate-sensitive binding sites exist in several states.

[ $\left.{ }^{3} \mathrm{H}\right]$ Glutamate binding; $\left[{ }^{3} \mathrm{H}\right] \mathrm{AMPA}$ binding; Thiocyanate; (Autoradiography, Receptor, Rat)

\section{Introduction}

Based on conventional electrophysiological techniques, AMPA ([RS]- $\alpha$-amino-3-hydroxy-5methylisoxazole-4-proprionic acid) has been shown to be a potent agonist in the mammalian central nervous system at the quisqualate subtype of glutamate receptor (Krogsgaard-Larsen et al., $1980 ; 1985)$. Binding studies of the quisqualate receptor using $\left[{ }^{3} \mathrm{H}\right]$ glutamate and $\left[{ }^{3} \mathrm{H}\right] \mathrm{AMPA}$ have yielded conflicting results, however. $\left[{ }^{3} \mathrm{H}\right]$ Glutamate binding to quisqualate-sensitive binding sites is highly chloride- and calcium-dependent whereas $\left[{ }^{3} \mathrm{H}\right] \mathrm{AMPA}$ binding is relatively insensitive to calcium and chloride (Greenamyre et al., 1984; Rainbow et al., 1984; Cha et al., 1988). Autoradiograms of $\left[{ }^{3} \mathrm{H}\right] \mathrm{AMPA}$ binding in the absence of

\footnotetext{
* To whom all correspondence should be addressed: Neuroscience Laboratory Building, 1103 E. Huron, Ann Arbor, MI 48104-1687, U.S.A.
}

thiocyanate consistently demonstrate low levels of binding (Monaghan et al., 1984; Rainbow et al., 1984; Olsen et al., 1987). Recent studies of $\left[{ }^{3} \mathrm{H}\right]$ AMPA binding have shown a marked sensitivity to thiocyanate (Honoré and Nielsen, 1985; Murphy et al., 1987). In order to investigate the relationship between $\left[{ }^{3} \mathrm{H}\right] \mathrm{AMPA}$ binding sites and quisqualate-sensitive $\left[{ }^{3} \mathrm{H}\right]$ glutamate binding sites, we have studied the binding of both ligands under various ionic conditions in the rat brain. Based on these data, we propose a model of quisqualatesensitive binding sites which will account for these various ionic and ligand binding effects.

\section{Materials and methods}

\subsection{Materials}

L- $\left[{ }^{3} \mathrm{H}\right]$ Glutamic acid (specific activity 53 $\mathrm{Ci} / \mathrm{mmol}$ ) was obtained from Amersham (Arling- 
ton Heights, IL) and $\left[{ }^{3} \mathrm{H}\right] \mathrm{AMPA}$ (24.5-27.6 $\mathrm{Ci} / \mathrm{mmol}$ ) was obtained from New England Nuclear (Boston, MA). Non-radioactive AMPA was a gift from Dr. Povl Krogsgaard-Larsen. All other compounds were purchased from Sigma (St. Louis, MO).

\subsection{Tissue preparation}

Male Sprague-Dawley rats (175-250 g) were decapitated, and the brains were quickly removed, mounted with Lipshaw embedding matrix on a cryotome chuck, and frozen under powdered dry ice. Sections, $20 \mu \mathrm{m}$, were cut on a Lipshaw cryostat and thaw-mounted onto gelatin-coated slides. Sections were stored for less than $24 \mathrm{~h}$ at $-20^{\circ} \mathrm{C}$. In order to remove endogenous glutamate, all sections underwent a wash for $30 \mathrm{~min}$ at $2^{\circ} \mathrm{C}$ in either $50 \mathrm{mM}$ Tris- $\mathrm{HCl}$ buffer (Tris- $\mathrm{HCl}$ ) containing $2.5 \mathrm{mM} \mathrm{CaCl}_{2}, \mathrm{pH} 7.20$ or $50 \mathrm{mM}$ Tris-acetate buffer (Tris-Ac), pH 7.20. Sections were blown dry under a stream of room temperature air.

\subsection{Receptor autoradiography}

A detailed description of the method for glutamate binding autoradiography has been published (Greenamyre et al., 1984). Briefly, in competition studies tissues were incubated for $45 \mathrm{~min}$ at $2^{\circ} \mathrm{C}$ with various competitors in the presence of $200 \mathrm{nM}\left[{ }^{3} \mathrm{H}\right]$ glutamate (specific activity 4.2-7.3 $\mathrm{Ci} / \mathrm{mmol}$ ) in a total volume of $8 \mathrm{ml}$. In the presence of $100 \mu \mathrm{M}$ NMDA, greater than $95 \%$ of $\left[{ }^{3} \mathrm{H}\right]$ glutamate binding was displaceable by 2.5 $\mu \mathrm{M}$ quisqualate. All solutions were adjusted to $\mathrm{pH}$ 7.2 with either Tris base, acetic acid, or hydrochloric acid prior to use. Non-specific binding was defined as that $\left[{ }^{3} \mathrm{H}\right]$ glutamate binding occurring in the presence of $1 \mathrm{mM}$ unlabelled glutamate and represented less than $10 \%$ of the total binding of $\left[{ }^{3} \mathrm{H}\right]$ glutamate. For $\left[{ }^{3} \mathrm{H}\right] \mathrm{AMPA}$ binding, the tissue was incubated for $45 \mathrm{~min}$ at $2^{\circ} \mathrm{C}$ with $20-75 \mathrm{nM}$ of $\left[{ }^{3} \mathrm{H}\right]$ AMPA. Non-specific binding was determined in the presence of $100 \mu \mathrm{M}$ unlabelled AMPA or $1 \mathrm{mM}$ glutamate and, in the presence of potassium thiocyanate, represented less than $5 \%$ of total binding. In the absence of thiocyanate, the non-specific binding represented less than $15 \%$ of total binding. In experiments examining the effects of calcium and chloride, these ions were added as acetate and Tris salts, respectively. Thiocyanate ions were added as potassium thiocyanate. Non-specific binding was determined under each ionic condition.

After the incubation, sections were rinsed quickly 3 times with cold buffer, then rinsed with cold $2.5 \%(\mathrm{v} / \mathrm{v})$ glutaraldehyde in acetone. Sections were blown dry with warm air. The rinse/ drying procedure took no more than $10 \mathrm{~s}$. Dried sections were placed in X-ray cassettes with appropriate radioactive standards (Pan et al., 1983) and apposed to LKB Ultrofilm ${ }^{3} \mathbf{H}$. The film was exposed to the tissue sections for 14-21 days at $4^{\circ} \mathrm{C}$, then developed, fixed and dried. The optical densities of the resultant film images were determined using a computer-assisted microdensitometer (Dauth et al., 1984). Sixteen to twenty-five readings were averaged from each area of interest. The radioactivity was determined by a computergenerated polynomial regression analysis which compared film densities produced by the tissue sections to those produced by the radioactive standards. All data presented were analyzed densitometrically from autoradiographic images.

$K_{1}$ values were generated by the non-linear regression program LIGAND (Munson and Rodbard, 1980).

\section{Results}

3.1. Regional distribution of quisqualate-sensitive glutamate binding sites and $\left[{ }^{3} H\right] A M P A$ binding sites

Overall, $\left[{ }^{3} \mathrm{H}\right]$ AMPA binding had a distribution similar to that of quisqualate-sensitive $\left[{ }^{3} \mathrm{H}\right]$ glutamate binding, although differing somewhat in hippocampus and cerebellum (table 1) (fig. 1). In hippocampus, binding was higher in stratum radiatum and molecular layer of dentate gyrus for $\left[{ }^{3} \mathrm{H}\right] \mathrm{AMPA}$ as compared to quisqualate-sensitive $\left[{ }^{3} \mathrm{H}\right]$ glutamate binding. In cerebellar molecular layer, binding was relatively less for $\left[{ }^{3} \mathrm{H}\right] \mathrm{AMPA}$ than it was for quisqualate-sensitive $\left[{ }^{3} \mathrm{H}\right]$ gluta- 
TABLE 1

Regional localization of quisqualate-sensitive $\left[{ }^{3} \mathrm{H}\right]$ glutamate binding and $\left[{ }^{3} \mathrm{H}\right] \mathrm{AMPA}$ binding in 11 regions of rat brain. Values represent the average \pm S.E.M. in readings from four rats. Percentages represent binding as compared to binding in the dentate gyrus.

\begin{tabular}{lll}
\hline Region & \multicolumn{2}{l}{ Bound radioligand in pmol/mg protein } \\
\cline { 2 - 3 } & Quisqualate-sensitive binding ${ }^{a}$ & $\left.{ }^{3}{ }^{3}\right]_{A M P A}$ binding $^{b}$ \\
\hline Cerebral cortex & & \\
Somatosensory & $2.26 \pm 0.55(81.6 \%)$ & $3.71 \pm 0.04(71.6 \%)$ \\
$\quad$ Layers I, II & $0.89 \pm 0.44(32.1 \%)$ & $2.21 \pm 0.05(42.7 \%)$ \\
$\quad$ Layers V, VI & $1.68 \pm 0.44(60.6 \%)$ & $2.97 \pm 0.07(57.3 \%)$ \\
Anterior cingulate & & $5.18 \pm 0.04(=100 \%)$ \\
Hippocampal formation & $2.77 \pm 0.49(=100 \%)$ & $4.78 \pm 0.55(92.3 \%)$ \\
Dentate gyrus & $1.96 \pm 0.48(70.8 \%)$ & $4.10 \pm 0.06(79.2 \%)$ \\
Stratum radiatum of CA1 & $1.40 \pm 0.42(50.5 \%)$ & $2.05 \pm 0.10(39.6 \%)$ \\
CA3 & $1.12 \pm 0.36(40.4 \%)$ & $1.09 \pm 0.02(21.0 \%)$ \\
Striatum & $0.60 \pm 0.25(21.7 \%)$ & $1.09 \pm 0.01(30.3 \%)$ \\
Thalamus & $0.75 \pm 0.21(27.1 \%)$ & \\
Inferior colliculus & & $2.64 \pm 0.21(51.0 \%)$ \\
Cerebellum & $1.73 \pm 0.32(62.5 \%)$ & $1.23 \pm 0.08(23.8 \%)$ \\
Molecular layer & $0.50 \pm 0.20(18.1 \%)$ & \\
Granule cell layer &
\end{tabular}

a Quisqualate-sensitive $\left[{ }^{3} \mathrm{H}\right]$ glutamate binding was carried out in $200 \mathrm{nM}\left[{ }^{3} \mathrm{H}\right]$ glutamate (specific activity $6.72 \mathrm{Ci} / \mathrm{mmol}$ ) in $50 \mathrm{mM}$ Tris- $\mathrm{HCl}, 2.5 \mathrm{mM} \mathrm{CaCl}{ }_{2}, 100 \mathrm{mM} \mathrm{KSCN}$ and $1 \mathrm{mM} \mathrm{NMDA.}{ }^{b}\left[{ }^{3} \mathrm{H}\right] \mathrm{AMPA}$ binding was carried out in $20 \mathrm{nM}\left[{ }^{3} \mathrm{H}\right] \mathrm{AMPA}$ (specific activity $25 \mathrm{Ci} / \mathrm{mmol}$ ) in $50 \mathrm{mM}$ Tris- $\mathrm{HCl}, 2.5 \mathrm{mM} \mathrm{CaCl}_{2}$ and $100 \mathrm{mM} \mathrm{KSCN}$.

mate binding. In the cerebellar molecular layer, specific $\left[{ }^{3} \mathrm{H}\right]$ AMPA binding in Tris- $\mathrm{HCl}$ buffer with $2.5 \mathrm{mM} \mathrm{CaCl}_{2}$ comprised $87 \%$ of total binding, with other areas demonstrating equal or higher percentages of specific binding. Similarly, specific $\left[{ }^{3} \mathrm{H}\right]$ glutamate was greater than $90 \%$ in all areas tested. All of the $\left[{ }^{3} \mathrm{H}\right] \mathrm{AMPA}$ binding was displaceable by quisqualate $(2.5 \mu \mathrm{M})$ and also by kainate $(100 \mu \mathrm{M})$.

\subsection{Effects of chloride and calcium on ligand bind- ing}

Chloride and calcium exerted a marked stimulation of quisqualate-sensitive $\left[{ }^{3} \mathrm{H}\right]$ glutamate binding as has been previously reported (Greenamyre et al., 1984; 1985). Levels of binding in the cerebellar molecular layer were increased 4-fold in $\mathbf{4 0}$ $\mathrm{mM}$ chloride and $2.5 \mathrm{mM}$ calcium versus Tris-Ac buffer (table 2). The increase in $\left[{ }^{3} \mathrm{H}\right]$ glutamate binding effected by calcium and chloride was due entirely to an increase in the quisqualate-sensitive binding sites and not to a change in N-methyl-Daspartate-sensitive or kainate-sensitive binding sites (Cha et al., 1988). The cerebellar molecular layer is the brain region which possesses both the highest absolute levels and highest proportion of quisqualate-sensitive $\left[{ }^{3} \mathrm{H}\right]$ glutamate binding sites (versus quisqualate-insensitive sites) (Cha et al., 1988). In the absence of thiocyanate, chloride ions slightly enhanced $\left[{ }^{3} \mathrm{H}\right] \mathrm{AMPA}$ binding, but the stimulation observed was much less than chloride's stimulation of $\left[{ }^{3} \mathrm{H}\right]$ glutamate binding. In the $\mathrm{ab}$ sence or presence of calcium and chloride $\left[{ }^{3} \mathrm{H}\right]$ AMPA binding was present only at low levels in all brain regions investigated.

\subsection{Effects of thiocyanate on ligand binding}

Quisqualate-sensitive $\left[{ }^{3} \mathrm{H}\right]$ glutamate binding was not affected by the presence of $100 \mathrm{mM}$ thiocyanate (table 2). Thiocyanate increased the ability of AMPA to displace $\left[{ }^{3} \mathrm{H}\right]$ glutamate binding (Cha et al., 1988). In the absence of 


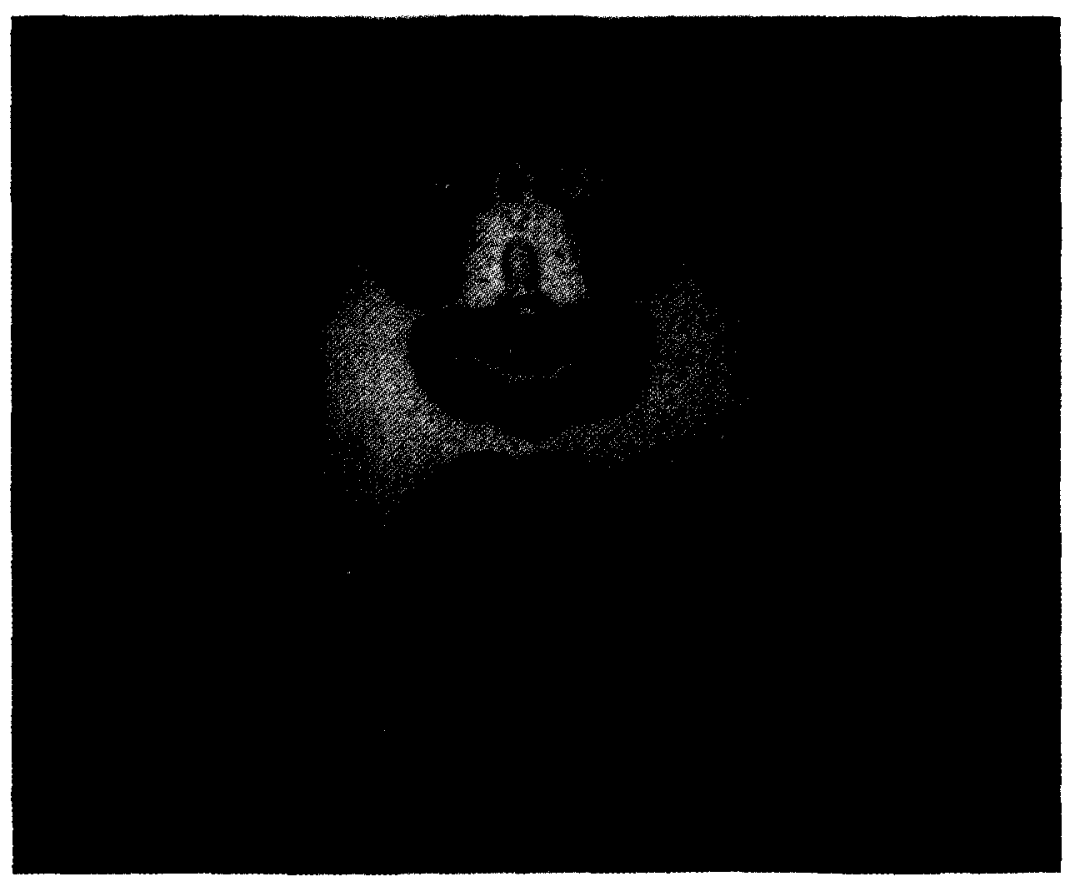

Fig. 1. Digitized images of autoradiograms of quisqualate-sensitive $\left[{ }^{3} \mathrm{H}\right]$ glutamate binding and $\left[{ }^{3} \mathrm{H}\right] \mathrm{AMPA}$ binding in horizontal sections of rat brain. Upper left: total $\left[{ }^{3} \mathrm{H}\right]$ glutamate binding $(200 \mathrm{nM})$ in $50 \mathrm{mM}$ Tris- $\mathrm{HCl}+2.5 \mathrm{mM} \mathrm{CaCl}, 100 \mathrm{mM}$ thiocyanate and $100 \mu \mathrm{M}$ NMDA. Lower left: same as in upper left, with the addition of $100 \mu \mathrm{M}$ AMPA. Upper middle: total [ ${ }^{3} \mathrm{H}$ ]AMPA binding ( $37 \mathrm{nM}$ ) in $50 \mathrm{mM}$ Tris- $\mathrm{HCl}+2.5 \mathrm{mM} \mathrm{CaCl}_{2}$ and $100 \mathrm{mM}$ thiocyanate. Upper right: total [ ${ }^{3} \mathrm{H}$ ]AMPA binding (37 $\mathrm{nM}$ ) in 50 $\mathrm{mM}$ Tris- $\mathrm{HCl}+2.5 \mathrm{mM} \mathrm{CaCl}_{2}$. Lower middle: $\left[{ }^{3} \mathrm{H}\right] \mathrm{AMPA}$ binding as in upper middle panel but in the presence of $100 \mu \mathrm{M}$ kainate. Lower right: $\left[{ }^{3} \mathrm{H}\right] \mathrm{AMPA}$ binding as in upper middle panel but in the presence of $100 \mu \mathrm{M}$ NMDA. The upper and lower left images are serial sections digitized from the same film under identical conditions. The four images on the right are also serial sections

exposed to the same film and digitized under the same conditions. The results are representative of findings in four different rats.

\section{TABLE 2}

Effects of calcium chloride and thiocyanate on quisqualate-sensitive $\left[{ }^{3} \mathrm{H}\right]$ glutamate and $\left[{ }^{3} \mathrm{H}\right] \mathrm{AMPA}$ binding in cerebellar molecular layer. Values represent the average of readings in four rats that varied less than $20 \%$ (pmol $/ \mathrm{mg}$ protein).

\begin{tabular}{|c|c|c|}
\hline$\overline{\text { Condition }}$ & $\begin{array}{l}\text { Quisqualate sensitive } \\
{\left[{ }^{3} \mathrm{H}\right] \text { Glutamate binding }}\end{array}$ & {$\left[{ }^{3}\right.$ H]AMPA binding ${ }^{b}$} \\
\hline $50 \mathrm{mM}$ Tris-Ac & 0.89 & 0.94 \\
\hline $50 \mathrm{mM}$ Tris-Ac $+100 \mathrm{mM} \mathrm{KSCN}$ & - & 3.67 \\
\hline 50 mM Tris- $\mathrm{HCl}$ & 2.70 & 1.15 \\
\hline $50 \mathrm{mM}$ Tris- $\mathrm{HCl}+100 \mathrm{mM} \mathrm{KSCN}$ & - & 4.11 \\
\hline $50 \mathrm{mM}$ Tris-Ac $+2.5 \mathrm{mM}$ Ca-acetate & 0.92 & 0.65 \\
\hline \multicolumn{3}{|l|}{$50 \mathrm{mM}$ Tris-Ac, $2.5 \mathrm{mM}$ Ca-acetate } \\
\hline$+100 \mathrm{mM} \mathrm{KSCN}$ & - & 3.33 \\
\hline $50 \mathrm{mM}$ Tris- $\mathrm{HCl}+2.5 \mathrm{mM} \mathrm{CaCl}_{2}$ & 3.60 & 1.24 \\
\hline $50 \mathrm{mM}$ Tris- $\mathrm{HCl}, 2.5 \mathrm{mM} \mathrm{CaCl}_{2}$ & 340 & 360 \\
\hline
\end{tabular}

${ }^{a}$ Quisqualate-sensitive $\left[{ }^{3} \mathrm{H}\right]$ glutamate binding was carried out at $200 \mathrm{nM}\left[{ }^{3} \mathrm{H}\right]$ glutamate (specific activity $6.1 \mathrm{Ci} / \mathrm{mmol}$ ). ${ }^{\mathrm{b}}\left[{ }^{3} \mathrm{H}\right] \mathrm{AMPA}$ binding was carried out at $60 \mathrm{nM}\left[{ }^{3} \mathrm{H}\right] \mathrm{AMPA}$ (specific activity $27.6 \mathrm{Ci} / \mathrm{mmol}$ ). 
thiocyanate, AMPA (up to $100 \mu \mathrm{M}$ ) displaced less than $20 \%$ of $\left[{ }^{3} \mathrm{H}\right]$ glutamate binding in molecular layer of cerebellum whereas in the presence of 100 $\mathrm{mM}$ thiocyanate, concentrations of AMPA up to $100 \mu \mathrm{M}$ displaced as much as $44 \%$ of glutamate binding. Thus, in the presence of thiocyanate, AMPA displaced a portion, but not all of the quisqualate-sensitive $\left[{ }^{3} \mathrm{H}\right]$ glutamate binding, even at the relatively high concentration of $100 \mu \mathrm{M}$. Thiocyanate had similarly dramatic effects on $\left[{ }^{3} \mathrm{H}\right]$ AMPA binding. In the presence of $100 \mathrm{mM}$ thiocyanate, $\left[{ }^{3} \mathrm{H}\right] \mathrm{AMPA}$ binding increased 5-fold in the molecular layer of cerebellum. The stimulatory effects of thiocyanate did not require the presence of chloride or calcium ions, with $100 \mathrm{mM}$ $\mathrm{KSCN}$ exerting as much stimulatory effect in TrisAc buffer as in Tris- $\mathrm{HCl}$ buffer with $2.5 \mathrm{mM}$ $\mathrm{CaCl}_{2}$. The Pearson correlation coefficient of the regional distribution of $\left[{ }^{3} \mathrm{H}\right] \mathrm{AMPA}$ binding in the presence of thiocyanate compared to quisqualatesensitive $\left[{ }^{3} \mathrm{H}\right]$ glutamate binding was 0.94 when examined in 11 brain regions. However, when AMPA-displaceable $\left[{ }^{3} \mathrm{H}\right]$ glutamate binding in the

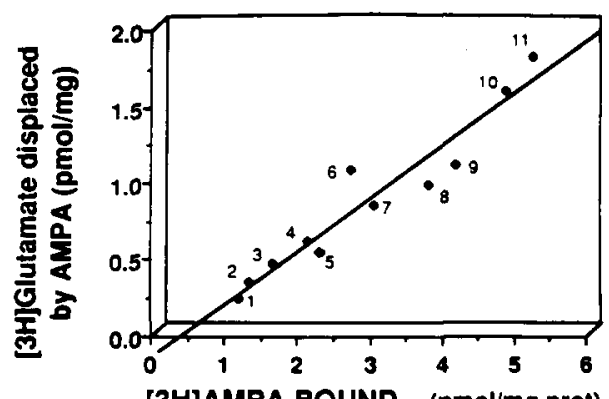

Fig. 2. Correlation between the distribution of AMPA displaceable quisqualate-sensitive $\left[{ }^{3} \mathrm{H}\right]$ glutamate binding and $\left[{ }^{3} \mathrm{H}\right]$ AMPA binding in 11 regions of rat brain. AMPA displaceable quisqualate-sensitive $\left[{ }^{3} \mathrm{H}\right]$ glutamate binding was determined by subtracting binding of $\left[{ }^{3} \mathrm{H}\right]$ glutamate $(200 \mathrm{nM})$ in $50 \mathrm{mM}$ Tris- $\mathrm{HCl}, 2.5 \mathrm{mM} \mathrm{CaCl}_{2}, 100 \mathrm{mM} \mathrm{KSCN}, 100 \mu \mathrm{M}$ NMDA and $100 \mu \mathrm{M}$ AMPA from total $\left[{ }^{3} \mathrm{H}\right]$ glutamate binding under the same conditions in the absence of AMPA. $\left[{ }^{3} \mathrm{H}\right] \mathrm{AMPA}$ binding ( $37 \mathrm{nM}$ ) was carried out in $50 \mathrm{mM}$ Tris- $\mathrm{HCl}, 2.5 \mathrm{mM}$ $\mathrm{CaCl}_{2}$ and $100 \mathrm{mM} \mathrm{KSCN}$. Regions: 1, thalamus; 2, granule layer of cerebellum; 3 , inferior colliculus; 4 , striatum; 5 , inner layers of cerebral cortex; 6 , molecular layer of cerebellum; 7 , cingulate cortex; 8, outer layers of the cerebral cortex; $9, \mathbf{C A}_{4}$ region of hippocampus; 10 , stratum radiatum of $\mathrm{CA}_{1} ; 11$, stratum moleculare of the dentate gyrus. The Pearson correlation coefficient was $r=0.97(P<0.0005)$. presence of calcium, chloride, and thiocyanate was compared to $\left[{ }^{3} \mathrm{H}\right]$ AMPA binding, the two correlated even more significantly $(r=0.97, P<0.0005)$ (fig. 2).

\section{Discussion}

According to the most common classification scheme, excitatory amino acid receptors are classified into at least three subclasses, named for the glutamate analogs which preferentially act at them: NMDA receptors, kainate receptors and quisqualate receptors (Watkins and Evans, 1981). While quisqualate acts preferentially at one class of receptors, it possesses actions at non-quisqualate receptors (Olverman et al., 1984; Greenamyre et al., 1985; Foster and Fagg, 1987; Cha et al., 1988). Much of the lack of specificity of quisqualate's actions may be attributable to contamination of quisqualate by glutamate (Olverman et al., 1984; Cha et al., 1987). The non-selective actions of quisqualate mediated by contaminants are accentuated when high concentrations of quisqualate are employed. We have previously demonstrated that many commercially available preparations of quisqualic acid possess contaminant glutamic acid. However, we have employed quisqualate which is greater than $99 \%$ free from contaminant glutamate, as determined by high performance liquid chromatography (HPLC) analysis (Cha et al., 1987). While the prospect of spurious effects due to contaminants must be considered, at the concentrations of quisqualate which we employ to define 'quisqualate-sensitive' $\left[{ }^{3} \mathrm{H}\right]$ glutamate binding $(2.5 \mu \mathrm{M})$, the expected contribution from contaminant glutamate would be minimal.

In addition, quisqualate has been shown to interact with various other sites, including an astrocytic membrane binding site (Bridges et al., 1987), glutamate uptake processes (Pin et al., 1984; Zaczek et al., 1987; Kessler et al., 1987), and the enzyme which metabolizes the dipeptide $\mathrm{N}$ acetyl-aspartyl-glutamate (NAAG) (Robinson et al., 1987). We have previously shown that quisqualate's displacement of $\left[{ }^{3} \mathrm{H}\right]$ glutamate from quisqualate-sensitive binding sites has a $\mathrm{K}_{\mathrm{I}}$ value which is at least 10 -fold lower than those found 
for any of the above mentioned processes (Cha et al., 1988). Thus, at the relatively low concentrations we have employed, quisqualate is likely to be a selective agent.

Nonetheless, AMPA may be a more selective ligand for the quisqualate subtype of glutamate receptor. Electrophysiological studies have demonstrated that AMPA has properties very similar to those of quisqualate in depolarizing membranes (Krogsgaard-Larsen et al., 1985), and has powerful pharmacological effects after local injection into various brain areas in the rat (Arnt, 1981a,b). AMPA also has similar neurotoxic effects to quisqualate (Morgan, 1987). In single channel studies, AMPA opens channels with similar ionic conductances and open channel times as does quisqualate (Christiansen and Nowak, 1987).

The regional correlation between levels of quisqualate-sensitive $\left[{ }^{3} \mathrm{H}\right]$ glutamate binding and $\left[{ }^{3} \mathrm{H}\right] \mathrm{AMPA}$ binding was excellent, with $\mathrm{r}=0.94$, suggesting that these two binding sites are the same or closely related. Some regional differences existed, however. The binding of $\left[{ }^{3} \mathrm{H}\right] \mathrm{AMPA}$ was relatively higher in the hippocampus as compared to $\left[{ }^{3} \mathrm{H}\right]$ glutamate binding and relatively lower in the molecular layer of the cerebellum. Secondly, even in the presence of thiocyanate ions, AMPA displaced only a portion of $\left[{ }^{3} \mathrm{H}\right]$ glutamate bound to quisqualate-sensitive sites. One possible interpretation of these differences is that $\left[{ }^{3} \mathrm{H}\right] \mathrm{AMPA}$ binds to a subpopulation of quisqualate-sensitive glutamate binding sites (Honoré and Nielsen, 1985). The studies reported here investigated that possibility.

The distribution of $\left[{ }^{3} \mathrm{H}\right] \mathrm{AMPA}$ binding sites correlated most highly with the distribution of quisqualate-sensitive $\left[{ }^{3} \mathrm{H}\right]$ glutamate displaced by unlabelled AMPA. These results suggest that AMPA may be binding to a subset of quisqualatesensitive $\left[{ }^{3} \mathrm{H}\right]$ glutamate binding sites, and its binding to this subset is dramatically increased by the presence of thiocyanate.

Honoré and Nielsen (1985) and Murphy et al. (1987) have shown that the addition of $100 \mathrm{mM}$ thiocyanate increases AMPA binding in homogenates several fold. In this autoradiographic study, $\left[{ }^{3} \mathrm{H}\right]$ AMPA binding was also increased dramatically in the presence of thiocyanate. The stimulatory effects of thiocyanate did not require the presence of chloride or calcium ions. In addition, thiocyanate increased the ability of unlabelled AMPA to displace quisqualate-sensitive $\left[{ }^{3} \mathrm{H}\right]$ glutamate binding.

The binding of $\left[{ }^{3} \mathrm{H}\right]$ glutamate to quisqualatesensitive sites is of high affinity and unaffected by thiocyanate. Whereas calcium and chloride had only small effects on $\left[{ }^{3} \mathrm{H}\right] \mathrm{AMPA}$ binding, these ions substantially increased the binding of $\left[{ }^{3} \mathrm{H}\right]$ glutamate to quisqualate-sensitive sites. Despite the fact that the two ligands, $\left[{ }^{3} \mathrm{H}\right] \mathrm{AMPA}$ and $\left[{ }^{3} \mathrm{H}\right]$ glutamate, are differentially affected by these ions, the correlation of regional distributions of $\left[{ }^{3} \mathrm{H}\right] \mathrm{AMPA}$ and quisqualate-sensitive $\left[{ }^{3} \mathrm{H}\right]$ glutamate binding sites argues strongly that these sites are the same or closely related. The extremely close regional correlation of $\left[{ }^{3} \mathrm{H}\right] \mathrm{AMPA}$ binding and $\left[{ }^{3} \mathrm{H}\right]$ glutamate binding displaced by AMPA argues that it is AMPA which interacts with a subset of the quisqualate-sensitive sites labelled by $\left[{ }^{3} \mathrm{H}\right]$ glutamate and not vice versa. AMPA's ability to displace only a portion of quisqualate-sensitive $\left[{ }^{3} \mathrm{H}\right]$ glutamate binding sites suggests that some of these sites are AMPA-sensitive while others are AMPA-insensitive. These results suggest an hypothesis in which the quisqualate receptor exists in a low affinity quisqualate binding state which is converted in the presence of calcium and chloride to a second state which has high affinity for quisqualate. These first two affinity states have low affinity for AMPA. Finally, in this hypothesis, in the presence of thiocyanate, these low affinity AMPA sites are in equilibrium with a third state which possesses high affinity for AMPA.

\section{Acknowledgements}

We want to thank Zane Hollinsgworth for valuable technical assistance. Supported by NIH NRSA 5T32 GM 07863 and UHPHS Grant NS 19613.

\section{References}

Arnt, J., 1981a, Hyperactivity following injection of a glutamate agonist and 6,7-ADTN into rat nucleus accumbens and its inhibition by THIP, Life Sci. 28, 1597. 
Arnt, J., 1981b, Turning behavior and catalepsy after injection of excitatory amino acids into rat substantia nigra, Neurosci. Lett. 23, 337.

Bridges, R.J., M. Nieto-Sampedro, M. Kadri and C.W. Cotman, 1987, A novel chloride-dependent L- $\left[{ }^{3} \mathrm{H}\right]$ glutamate binding site in astrocyte membranes, J. Neurochem. 48, 1709.

Cha, J.J., J.T. Greenamyre, E.Ø. Nielsen, J.B. Penney and A.B. Young, 1988, Properties of quisqualate-sensitive L$\left[{ }^{3} \mathrm{H}\right]$ glutamate binding sites in rat brain as determined by quantitative autoradiography, J. Neurochem. 51, 469.

Cha, J.J., Z. Hollingsworth, J.T. Greenamyre, J. Collins, J.B. Penney and A.B. Young, 1987, Possible contamination of quisqualic acid by naturally occurring glutamic acid detected by quantitative autoradiography and HPLC analysis, Soc. Neurosci. Abstr. 13, 1564.

Christiansen, J.L. and L.M. Nowak, 1987, AMPA-activated channels in mammalian cerebellar neurons, Soc. Neurosci. Abstr. 13, 753.

Dauth, G.W., K.F. Frey and S. Gilman, 1984, A densitometer for quantitative autoradiography, J. Neurosci. Meth. 9, 241.

Foster, A.C. and G.E. Fagg, 1987, Comparison of L$\left[{ }^{3} \mathrm{H}\right]$ glutamate, D- $\left[{ }^{3} \mathrm{H}\right]$ aspartate, DL- $\left[{ }^{3} \mathrm{H}\right] \mathrm{AP5}$ and $\left[{ }^{3} \mathrm{H}\right]$ NMDA as ligands for NMDA receptors in crude postsynaptic densities from rat brain, European J. Pharmacol. 133, 291.

Greenamyre, J.T., J.M.M. Olson, J.B. Penney and A.B. Young, 1985, Autoradiographic characterization of N-methyl-Daspartate-, quisqualate- and kainate-sensitive glutamate binding sites, J. Pharmacol. Exp. Ther. 233, 254.

Greenamyre, J.T., A.B. Young and J.B. Penney, 1984, Quantitative autoradiographic distribution of $\mathrm{L}-\left[{ }^{3} \mathrm{H}\right] \mathrm{g}$ lutamatebinding sites in rat central nervous system, J. Neurosci. 4, 2133.

Honoré, T. and M. Nielsen, 1985, Complex structure of quisqualate-sensitive glutamate receptors in rat cortex, Neurosci. Lett. 54, 27.

Kessler, M., G. Petersen, H.M. Vu, M. Baudry and G. Lynch, 1987, L-Phenylalanyl-L-glutamate-stimulated, chloride-dependent glutamate binding represents glutamate sequestration mediated by an exchange system, J. Neurochem. 48, 1191.

Krogsgaard-Larsen, P., L. Brehm, J.S. Johansen, P. Vinzents, J. Lauridsen and D.R. Curtis, 1985, Synthesis and structureactivity studies on excitatory amino acids structurally related to ibotenic acid, J. Med. Chem. 28, 673.
Krogsgaard-Larsen, P., T. Honoré, J.J. Hansen, D.R. Curtis and D. Lodge, 1980, New class of glutamate agonist structurally related to ibotenic acid, Nature (London) 284, 64.

Monaghan, D.T., D. Yao and C.W. Cotman, 1984, Distribution of $\left[{ }^{3} \mathrm{H}\right]$ AMPA binding sites in rat brain as determined by quantitative autoradiography, Brain Res. 324, 160 .

Morgan, I.G., 1987, AMPA is a powerful neurotoxin in the chicken retina, Neurosci. Lett. 79, 267.

Munson, P.J. and D. Rodbard, 1980, Ligand: a versatile computerized approach for the characterization of ligand-binding systems, Anal. Biochem. 107, 220.

Murphy, D.E., E.,W. Snowhill and M. Williams, 1987, Characterization of quisqualate recognition sites in rat brain tissue using DL- $\left[{ }^{3} \mathrm{H}\right] \alpha$-amino-3-hydroxy-5-methylisoxazole-4-proprionic acid (AMPA) and a filtration assay, Neurochem. Res. 12, 775 .

Olsen, R.W., O. Szamraj and C.R. Houser, 1987, [ ${ }^{3}$ H]AMPA binding to glutamate receptor subpopulations in rat brain, Brain Res. 402, 243.

Olverman, H.J., A.W. Jones and J.C. Watkins, 1984, LGlutamate has a higher affinity than other amino acids for $\left[{ }^{3} \mathrm{H}\right]-\mathrm{D}-\mathrm{AP5}$ binding sites in rat brain membranes, Nature $307,460$.

Pan, H.S., K.F. Frey, A.B. Young and J.B. Penney, 1983, Changes in $\left[{ }^{3} \mathrm{H}\right]$ muscimol binding in substantia nigra, entopeduncular nucleus, globus pallidus and thalamus after striatal lesions as demonstrated by quantitative autoradiography, J. Neurosci. 3, 1189.

Pin, J.-P., J. Bockaert and M. Recasens, 1984, The $\mathrm{Ca}^{2+} / \mathrm{Cl}^{-}$ dependent $\mathrm{L}-\left[{ }^{3} \mathrm{H}\right]$ glutamate binding: a new receptor or a particular transport process?, FEBS Lett. 175, 31.

Rainbow, T.C., C.M. Wieczorek and S. Halpain, 1984, Quantitative autoradiography of binding sites for $\left[{ }^{3} \mathrm{H}\right]$ AMPA, a structural analogue of glutamic acid, Brain Res. 309, 173.

Robinson, M.B., R.D. Blakely, R. Couto and J.T. Coyle, 1987, Hydrolysis of the brain dipeptide $\mathrm{N}$-acetyl-L-aspartyl-Lglutamate: Identification and characterization of a novel $\mathrm{N}$-acetylated $\alpha$-linked acidic dipeptidase activity from rat brain, J. Biol. Chem. 262, 14498.

Watkins, J.C. and R.H. Evans, 1981, Excitatory amino acid transmitters, Ann. Rev. Pharmacol. Toxicol. 21, 165.

Zaczek, R., S. Arlis, A. Markl, T. Murphy, H. Drucker and J.T. Coyle, 1987, Characteristics of chloride-dependent incorporation of glutamate into brain membranes argue against a receptor binding site, Neuropharmacology 26, 281. 